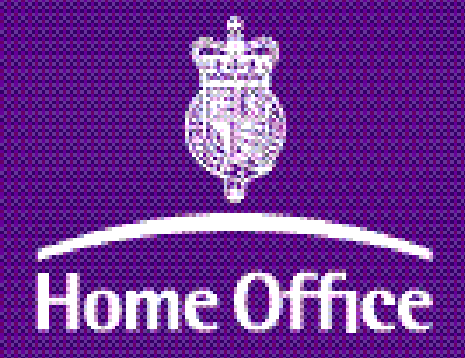

Tackling Domestic Violence: providing support for difldren who have withessed domestic violence

Palterns of Crime

Crime Reduction

Policing and Organised Crime Criminal Justice System Drugs and Alcohol Offenders Corrections Immigration and Asylum Social Cohesion and Civil Renewal Economic Analysis and Modelling 


\title{
Tackling Domestic Violence: providing support for children who have witnessed domestic violence
}

\author{
Professor Audrey Mullender, \\ University of Warwick
}

This report provides good practice recommendations and suggestions for a range of practitioners and professionals who have a role in commissioning, developing or delivering initiatives to support children who have in the past or are currently witnessing domestic violence. Once domestic violence has been identified and disclosed, children may need direct support to help them cope and move on from what has or is happening. Examples of the type of support work include: counselling, play therapy, life story work, crisis work and safety planning, and this can either be provided on a one-to-one basis or as part of group work. These interventions are often conducted in parallel with support work with the mother.

The report draws upon the evaluations of a number of projects which were funded under the remit of the Crime Reduction Programme (CRP) Violence Against Women Initiative (VAWI), as well as the available published literature. More information about the evidence base for this guidance is detailed at the end of this report.

\section{What is domestic violence?}

Domestic violence comprises a broad range of behaviours, which can often overlap. The Home Office's definition of domestic violence is as follows:

Any incident of threatening behaviour, violence or abuse (psychological, physical, sexual, financial or emotional) between adults who are or have been intimate partners or family members, regardless of gender or sexuality.

The 2001 British Crime Survey (BCS) included a selfcompletion module on domestic violence, and this is widely regarded as providing the most robust estimates, to what is understandably an under reported crime. The findings indicated that one in five (21\%) women and one in ten (10\%) men have experienced at least one incident of nonsexual domestic threat or force since they were 16 . If financial abuse is included, then 26 per cent of women and 17 per cent of men had experienced domestic violence since the age of 16 (Walby and Allen, 2004). Domestic violence affects all sections of society, regardless of age, gender, wealth, sexuality and geography. However, it is mainly women who suffer. The presence of children in the household is associated with nearly double the risk of domestic violence for women (Walby and Allen, 2004).
Children and their experience of domestic violence

According to the 1996 BCS, half of those who suffered domestic violence in the previous year were living with children aged 16 years or under (Mirrlees-Black, 1999). Children who live with domestic violence typically know it is happening; 29 per cent of those who had experienced domestic abuse in the previous year stated that children had been aware of what was going on during the last incidence of violence. Children were more likely to be witnesses to violence against women who had suffered repeated violence: 45 per cent of these women said children were aware of the last incident (Mirrlees-Black, 1999).

What children see or hear when their mothers are being abused can not only include physical violence but also emotional abuse and put-downs, threats and intimidation, sexual jealousy and abuse. Children may witness the family being kept short of money or the abuser taking money from other family members and also experience isolation from family and friends. Children typically know far more of what is going on than their parents' think. They may be in the next room listening or lying awake in bed, or they may pick up the atmosphere the next day. The National Children's Home (NCH) Action for Children study (2002) found that children living with domestic violence 
frequently experienced direct physical and sexual assault and that ten per cent had witnessed their mother being sexually assaulted.

They don't even have to see it - children are very perceptive and they know when their mother's upset or has been hurt or is anxious.

(Woman using outreach service)

Abusers may involve children in the abuse in a range of ways, such as making them watch or encouraging them to be abusive towards their mothers. There is also a recognised overlap between domestic violence and child sexual and physical abuse (Mullender, 2000). Many violent men have a tendency to punish children inappropriately and too harshly. Some make threats against the children, or hurt them, to frighten their mother. Many children want to protect their mothers and they may put themselves at risk in the process. Research shows that girls, in particular seek to protect younger siblings during violent episodes and offer support or reassurance in the aftermath of violent behaviour (Jaffe et al., 1990). Children may be at physical risk if they get in the way during an attack or if they intervene. When they have contact with fathers after separation, children may take on even greater responsibility to protect their mothers or siblings from violence or neglect (Hester and Radford, 1996). It is important to recognise children's wish to help and, where possible, to teach them safe ways to do this such as protecting their younger brothers and sisters or phoning for help where possible. (See Loosley et al., forthcoming 2004).

Sometimes children have to leave home, leaving everything behind (clothes, toys, pets, family and friends, school), without understanding why. This may be to go to a refuge that is totally unlike anywhere they have ever lived before (Mullender et al., 2002) or because so many refuges are full, it may include spells in temporary accommodation, such as a bed and breakfast hotel or a hostel where there are no special security arrangements. The process of leaving may take many months, or even years, and it may involve leaving and returning several times. Leaving home is not enough to guarantee safety; women and children may be assaulted by their partner or ex-partner, (Walby and Allen, 2004) after moving away. Abusers who leave the family may also continue to pose a threat (Walby and Myhill, 2000; Walby and Allen, 2004). Until they can feel absolutely safe, children continue to suffer.

Children are an integral factor in the mother's management of their abusive relationships. For more than half the participants in a research study, something the children said or did catalysed the woman into seeking help (Zink et al., 2003).
However, even after women have left violent partners, there is a risk of child contact arrangements being used by the man to continue a pattern of post-separation violence and harassment.

\section{Examples of problems with contact}

A woman who had separated from her violent partner found that it took two years to sort out contact issues, only for the arrangement to break down again completely because the perpetrator mistreated his daughter during contact visits. From the way he talked, he appeared to be trying to get at her mother through her.

A violent father was verbally abusive at an unsupervised contact centre towards his seven-year-old daughter, whom he had not seen for two years - goading her and preventing her from leaving until she spat at him. He later tried to snatch her and, over time, made several attempts to obtain a residence order. The girl was under great stress and felt no one was listening to what she wanted because the court had enforced contact against her wishes. Eventually, she had to see a psychiatrist about the emotional and psychological problems she developed.

\section{How does domestic violence impact upon children?}

Children can be affected in many different ways by living with domestic violence. There is no set pattern of signs or symptoms. Some children come through relatively unscathed, for example if they have good ways of coping, or people to turn to for support, or if they are less aware of what is going on. Others recover well once they feel safe (Wolfe et al., 1986; Mullender et al., 2002)

However, children are likely to be affected by the fear, disruption and distress in their lives. Children show distress in their own ways, depending on their age and developmental stage. They may have physical, emotional, learning, behavioural or developmental problems, and their educational performance and achievement may also be affected. These symptoms can easily be misdiagnosed or wrongly assessed as illness, permanent learning difficulties or naughtiness (Mullender, 2000).

Kitzmann et al. (2003) found from a meta-analysis of 118 studies of psychosocial outcomes of children exposed to domestic violence, that there was a significant association between exposure to domestic violence and child problems. Group comparison studies showed that children who had witnessed domestic violence had significantly worse psychosocial outcomes relative to children who had not witnessed domestic violence. Children who had witnessed domestic violence had similar outcomes to those of physically abused children. 
Furthermore, children learn that the abuse of their mother is something that isn't talked about, either at home or outside, this makes it harder for them to seek explanations about all the confusing things that are happening and much harder to ask for help.

One seven-year-old boy, whose mother was helped by an outreach service, had difficulty expressing himself emotionally, difficulties at school and behavioural problems. He had seen his mother and sister physically attacked, and had himself suffered constant verbal abuse. His mother felt that he needed counselling or some other kind of help to talk about how he felt.

Often, in a small community, the professionals that one would approach may know the family well or could live nearby; thus victims and their children are reluctant to approach them. Similarly, minority ethnic children may be forced by the violence to leave a supportive community and may face discriminatory attitudes from relevant agencies (Mullender, 2000). Many Area Child Protection Committees (ACPCs) have found it useful to set up working groups to provide specialist advice on working with specific ethnic or cultural groups or children who have special needs and their parents (Department of Health, 1999).

\section{How should professionals respond?}

\section{Disclosure}

It is important for all professionals working with children, including teachers, social workers, health visitors, psychologists and doctors to:

- find safe and confidential ways of asking children what is really wrong when they see any of the symptoms mentioned in the previous section;

- recognise violence at home as one of the common reasons for problems in children's lives;

- give them a chance to talk;

- believe what they say; and

- know what help is available for them, and their mothers.

Children who disclose to professionals that they are living with abuse should always be listened to and believed (Children's Subcommittee of the London Co-ordinating Committee to End Woman Abuse, London, Ontario, 1994; Department of Health, 2003).

\section{Good practice pointer when children}

\section{disclose domestic violence}

Show that you take seriously what children are saying, and try to find ways to get appropriate help - straight away if the danger appears to be current.

Practitioners should be familiar with the government guidance on dealing with children who have been abused. See What to do if you are worried about a child being abused (Department of Health, 2003). This document also includes an appendix on when and how to share information about children with other agencies to help protect the wellbeing of the child.

\section{Training}

Practitioners, who conduct one-to-one sessions or group work, must receive training on how to effectively and appropriately work with children. They also need training on domestic violence that encompasses the abuse of power and control within intimate relationships, the manipulative patterns, threats and intimidation employed by perpetrators to conceal the abuse, and the coping strategies women and children use to survive. Without this knowledge, practitioners are likely to fail to identify and assess the very real risks facing some children and their mothers. At worst, they may blame abused women for their children's problems or miss the cause of these entirely and assume that the child is ill, developmentally delayed or behaviourally disturbed in some way.

\section{Inter-agency roles and responsibilities}

A wide range of services and professionals provide support to families in bringing up children. Both statutory and voluntary services can support families: by helping children to develop to their full potential, for example, through universal education and health services. By providing specialist help to those who need it, and by providing support or otherwise intervening at times of adversity or crisis or when support is provided on a compulsory basis in order to safeguard the child from significant harm as outlined in Working together to Safeguard Children (Department of Health, 1999); Framework for the Assessment of Children in Need and their Families (Department of Health, 2000); Every Child Matters (Department for Education and Skills, 2003).

Agencies need to make the appropriate referrals and intervene in the child's best interests, bearing in mind risk assessment and safety planning for the child. A key principle of the Framework for the Assessment of Children in Need and their Families (Department of Health, 2000), is that children's needs and their families 
circumstances will require inter-agency collaboration to ensure full understanding of what is happening and an effective service response. It requires that all staff understand the roles and responsibilities of staff working in contexts different to their own. An understanding of the perspectives, language and culture of other professionals and how they work can help communication between these groups (Department of Health, 2000; Department of Health, 2003; Department of Education and Skills, 2003).

\section{Police and Crown Prosecution Service (CPS)}

The HMIC/HMCPSI Inspectorate Report (2004) on domestic violence recommended that the police should note the details of any children as well as the impact of the crime on them when they are investigating domestic cases. A specialist police department should be notified of the situation and a domestic incident report should be completed. These details should also be included in any files, which are passed to the Crown Prosecution Service (CPS), so that the CPS can take the rights and safeguarding of children fully into account when prosecuting domestic violence cases.

The consideration of children as both victims and witnesses also needs to be addressed, and both guidance and training is required for the police and the CPS. The best interest of the child should be paramount when deciding whether and in what form support is given. Some children will have been interviewed by the police and may be witnesses in a criminal prosecution. This should be established before work is undertaken as outlined in Provision of Therapy for Child Witnesses Prior to a Criminal Trial (Home Office et al., 2001). At the same time, there is a need for all people who work with children before a criminal trial to be aware of the possible impact of their work upon subsequent evidence in the trial.

\section{How can direct work help children?}

The aim of direct work with children is to enable them to cope appropriately with the abuse they heard or witnessed, and importantly not to blame themselves for what is happening. Interventions can include all forms of individual face-to-face work - such as counselling, play therapy, life story work, crisis work and safety planning - and also work with children in groups.

The benefits include the chance for each child to:

- obtain permission to talk about what has happened at home;

- ventilate their pent-up feelings about the violence and its effect on their family;
- receive reassurance that it was not their fault that these things happened;

- rebuild their self-esteem; and

- develop individual safety plans for the future.

Groups have an added benefit of helping children discover that they are not alone in having had bad experiences.

One children's support worker interviewed was entirely new to children's groups. She was struck that children had never before had an opportunity to talk freely about their experiences since other children at school could not relate to these. The children she worked with badly needed someone who could understand and empathise. The group provided this, both through the workers and the other group members.

\section{Individual work}

Individual or 'one-to-one' work can be undertaken with children of any age from about four or five upwards, by a professional who has been specifically trained to work with children who have witnessed domestic abuse. Basically individual work can be one of two types:

- a piece of in-depth work focused around a particular issue; or

- it can be unstructured, going where the child wants to take it, at the child's pace and only as far as they want to go, using free expression through art, play or other forms of therapy designed to help 'unravel complex feelings', (as a project worker helpfully expressed it).

One CRP VAWI project confines work with children still living with ongoing domestic violence to safety work and a focus on 'protective behaviours' so that children can learn how to keep themselves safe and how to get help, for example by phoning the police. Only when the child is living in relative safety is more in-depth work attempted.

Children frequently need 'somewhere to off-load' (comment from a mother). Most work in the CRP VAWI projects, or in the units and centres to which they refer children, is conducted on a one-to-one basis. It is responsive to the issues children express or demonstrate:

The services we provide are anything from nondirective expressive work, emotional work or more direct work helping children develop an emotional vocabulary, or looking at divorce and separation and what it means to them.

(Interview with project worker) 
One-to-one work can meet children's individual needs, particularly around adjustment, emotions and behaviour, and was available in all the research sites that were also running children's groups. The specialist projects studied offer it to children who are the dependants of domestic violence victims being worked with and who are felt to have needs of their own. Referrals can come directly from mothers or from agencies such as social services and education, and they often come in the course of a general enquiry as to whether anything is available to support the children. Many referrals are from specialist projects, which primarily aim to support woman who have or are being abused.

However, it must be noted that sometimes not all referrals are appropriate, as there may be too many associated problems.

Below are some examples of how the projects, which were evaluated under the CRP VAWI, went about providing direct one-to-one support to the children of the women they were helping.

\section{Example 1}

In one project, an initial assessment with each mother regarding her child's needs is followed, if she consents, by meeting mother and child together and, finally, an assessment with the child to see what he or she expects from the sessions. An initial six-week programme of weekly sessions involves drawing, colouring, painting and playing. The workers do not raise the issue of domestic violence but let the child do so:

'They know why they've come. And we make that very clear - like: who we are, and what we do, and it's their space to look at these issues.'

'I had one little boy who actually said: "I want to come and I want to paint my feelings out and I want to go. I don't want to talk about it." And he does that.'

\section{Example 2}

In another project, an initial four-week block of individual sessions is booked for each child, with a review with the child's mother at the end of this period to determine whether to stop, continue or refer elsewhere. The child is also asked to indicate how he or she is now feeling, how well supported s/he is, whether there are people to talk to elsewhere and how well they are coping. The majority of children continue to be helped, sometimes over many months, for example if there are protracted court proceedings or contact issues through which the child needs support. There can be simultaneous referrals to Sure Start or other agencies. Planning and evaluation are undertaken before and after each session. Work may be done on self-esteem, self-protection, the family unit, school, feelings and/or past experiences. It is to some extent led by what children themselves want and is also dependent on age. Techniques include various forms of art work: painting, drawing, collage materials, clay and plasticine, feelings sheets. Other techniques involve the use of books on self-esteem and being safe, worksheets, puppets and dolls, therapeutic and also 'fun' games.

\section{Example 3}

A third project makes referrals to a therapist in a specialist unit who uses play therapy equipment to allow each child to explore their own world, with the worker listening and gently drawing them out through the play activities. One seven-year-old girl who was helped in this way, for example, just sat and played with sand for the first eight weeks until she felt ready to progress. She was the youngest in the family and had been demonstrating quite aggressive behaviour. Her advocacy worker felt she would benefit from some space for herself while the family was on the waiting list for parenting work. This child showed real improvements, becoming able to sleep and use the toilet on her own, which previously she had been too frightened to do, and generally feeling more confident. In addition, children and families were referred to several other agencies, including social services for child protection issues and the local Family Service Unit for family work.

Mothers commented on how much they valued the support offered to their children, because they recognised the adverse impact domestic violence has had on them. They particularly appreciated being kept informed about the work being done with their child. One mother did wonder whether her child was getting what he needed or whether he had only been playing, because his one-to-one session had been conducted using play materials. Even so, she said: 'sometimes I'll talk to him and, all of a sudden, feelings will come out'. Clearly, the work undertaken was helping him to get back in touch with these feelings and to release them, exactly as she had hoped.

\section{One-to-one work as an introduction to group work}

As well as being useful in its own right, individual work can be used as a precursor to a group. In Ontario, Canada (Loosley et al., forthcoming 2004) all groups for child witnesses of woman abuse are preceded by individual pregroup meetings with each child, and also with the child and his or her mother. This helps the child to know what to expect, introduces them to the workers and takes away 
some of their fears about attending the group. It also helps the workers to assess each child's readiness for the group. If a particular child is denying that there is anything wrong or is not yet ready to talk about the violence or to cope in a group setting, then some individual sessions before joining the group may be of value.

Occasionally, too, an individual session is offered at a later stage to a child, or to a mother and child together, alongside group membership, where a new issue has arisen at home or a mother reports particularly difficult behaviour (though this is more often dealt with over the phone). Finally, on odd occasions, the post-group meeting with mother and child, which is held to get their feedback on the group, may throw up new issues that require some individual follow-up.

\section{Which children can benefit from group work?}

Children from ages 4 to 16 can benefit from groups. Experience in Canada, where such work is long established (Mullender, 1994), suggests that groups tend to work best if fairly narrow age bands are chosen, always bearing in mind that a child's developmental stage (emotionally, intellectually, behaviourally) may be different from their chronological age. A good assessment and a degree of flexibility will help here. Boys, girls and children of all ethnicities, can participate.

As with any group, it is not good practice to have just one girl or one boy, or one minority ethnic member, or one child who is in any marked way different from the others. It is worth checking, for example, whether any children have disclosed sexual abuse. If only one child has done so, they may still feel very different from the others and unable to talk freely.

Most group workers in this field try to work with children who are out of danger and living somewhere relatively stable at the point of referral. This helps the children to get the most from the group and gives their mothers a chance to focus on the children's issues. At the same time, the research showed that workers have to be realistic. Stability can take years to achieve in situations of domestic violence and women who are survivors have to balance many issues in their lives. Expecting too much can make it hard to recruit enough members.

\section{What happens in the groups?}

Most groups, except those that are purely therapeutic in approach, include learning about what domestic violence is and that it is very common. This is very useful, as children are frequently confused and worried. They need to get the message that the violence was not the child's fault; that the abuser is responsible for his or her own actions; that violence is wrong; and that there is help available to enable them and their mother to be safe.

All sorts of materials can be used in groups, and games and exercises work well. Younger children particularly like activities, while older children can spend longer on discussion without becoming bored. There are specialist materials available (see resource list), including a recently updated manual from Canada (Loosley et al., forthcoming 2004) and a spin-off version covering work with four to sixyear-olds in more detail (Foote, 1998). One of the most successful activities in one of the groups studied had been watching a video about domestic violence with scenarios for discussion, including going into a refuge. Good discussions can be held around excerpts from the 'soaps', items in teen magazines, or anything else that features relationships and gender roles.

Gender content works best if it is completely embedded in the process and content of the group, not just added on (Loosley and Mullender, 2003). Opportunities that arise spontaneously can be used to discuss everyday things such as what jobs men and women do, or what they do in the home. Group workers need to remember that they themselves are also role models. If there is a man in the group work team, it is important that he helps serve out the snacks, does not dominate in the group, and so on. All the women working with the group should be strong, confident and caring females.

\section{Keeping safe}

Some of the groups studied, though not all, offered valuable content on how to keep safe and how to call for help if safe to do so. It is important to cover this material, given that most groups will have some members who are still in contact with the violent perpetrator. It is also vital to talk about the help that is available and about the support networks that children think they might be able to use.

\section{Number of sessions}

Most of the feedback from the group workers and from some of the children, suggested that groups should have been longer, at say, 12 weeks rather than 10. Interestingly, a similar shift has been made in the evaluated groups in Ontario, Canada (Loosley, forthcoming 2004).

\section{Preparing for the group work to finish}

It is important to prepare children for the end of the group and to mark this in some way. In one group, workers decided to develop a pack for members to take away at the end, together with a certificate of achievement for attending. In the USA and Canada, a pizza party is a common way of celebrating the last group meeting. 
Below are some examples of the group work from the CRP VAWI projects.

\section{Group example 1}

One group was aimed at 7- to 11-year-olds, with prestructured content over nine, mainly weekly, sessions. The workers would have liked to have run for 12 weeks, but could not do so for practical reasons. Afterwards, they did feel there had been too much to get through. The aims of the group were: to help children understand what had happened to them; what domestic violence is and that it is not OK; that it was not their fault or their mother's fault; that they were not the only ones who had experienced it; and to help them work on their feelings towards their mothers and their mother's abusers; their behaviour; their self-esteem and confidence; their right to be safe; their assumptions about gender roles in society; and their personal support network. Children recruited to the group were required to be living separately from the abuser and no longer seeing violence.

\section{Group example 2}

In another project, a ten-week, pre-structured format was used, though with space to incorporate current 'live' issues such as feelings about missing family members and losses in the family. Planned topics included:

- the child's family before and after separation;

- feelings about the violence and who was to blame;

- worries, fears and hopes;

- anger;

- problem-solving; and

- feeling good about oneself.

Art was used as a major technique, alongside group activities, because this was a strength of the group worker to whom the group work was contracted. This provided a good opportunity for exploring feelings such as anger, sadness, fear and feelings of powerlessness, wanting to make the abuse stop, and wanting to protect their mother.

\section{Group example 3}

For referral to a group at a third project, children had to be living in a safe environment, with both mother and child happy about the child attending the group. The first group ran for eight weeks but the children themselves felt they would have liked it to have been longer so the next group was extended to 12 weeks. More time was then available to spend on protective behaviours and dealing with angry feelings. One boy also suggested having continuing support meetings every few months, one of which was subsequently planned. The structure of the group was pre-planned but with flexibility to pursue the children's own issues.

\section{Groups can:}

- help children to think about gender roles and to learn that these must not be rigid or demeaning;

- help children learn to keep safe; and

- help children learn that:

* violence is wrong and no one need put up with it;

* they are not the only one who has lived with violence;

* it is okay to talk about violence;

* boys need not grow up to be violent or abusive;

* girls need not expect to be hit when they grow up;

* relationships need not be violent or demeaning; and

* we all make choices about whether we are violent or whether we respect other people and their views.

\section{Some good practice pointers about group work}

- Remember that group work with children who have lived with domestic violence requires training:

i. about children;

ii. about groups; and

iii. about domestic violence.

- It is important to be prepared. Read the literature that is available and think about the main areas to cover. Have plenty of activities for the younger children and some discussion points for the older ones.

- At the same time, be flexible. The secret of good group work is following opportunities for positive experiences and new learning as they emerge, not sticking rigidly to a pre-set agenda.

- Think about involving a volunteer, a social work student or another suitable person to boost your numbers. If you have three workers in a group of young children, for example, you will be better able to cope with any particularly demanding children, and with any individual needs or mishaps that might otherwise interrupt the group.

- Expect high spirits, a fast pace and a limited concentration span from the youngest children. Have plenty of exercises ready, take a snack break, and allow some time just for play.

- Expect some drop-outs from the group. It might be an idea to start with the maximum number you feel you can deal with, given the age group and the 
number of workers, in case the numbers drop over time. It is difficult to have maximum success with group interaction in the group if numbers reduce too far. Staying in touch with mothers in between sessions may help with attendance.

- Think, too, about providing transport to and from the group. In the aftermath of domestic violence, women may find that making these practical arrangements and finding the money for fares is harder than usual which, again, can affect attendance.

- Be understanding with mothers when they are still emerging from crisis. Having other things on their minds doesn't mean that they don't love and care about their children. They may still be living in fear, coping with a court case, and so on. Try and put yourself in their place.

- Remember that danger doesn't start and finish on a certain date. Contact after separation or divorce, whether informal or arranged through the courts, can mean that the perpetrator is still on the scene and may still present a threat. Some children may still be very scared of the perpetrator, while others may have confused loyalties. Bear this in mind in what you say and do in the group.

- Workers need to debrief and plan between each session.

- Seek good supervision and/or expert consultancy. This is challenging and skilled work that you should not undertake without appropriate support.

\section{Children have different needs}

- Children and young people may have additional needs, which may be due to: learning difficulties; problems with reading and writing; physical, sight or hearing impairments; specific cultural requirements; or a lack of comprehension of English, etc. Each child's needs should be assessed on an individual basis, and additional steps should be taken to ensure they are met. For example, this may entail using workers from the same cultural or ethnic background, and/or who can speak the same language; it may mean employing someone who can use British Sign Language (BSL) or ensuring resources are available in a range of community languages. Such measures should be familiar to many agencies as part of their general provision of a client-centred, and culturally sensitive and competent service.
- It can also be hard to meet the needs of children in rural areas, as individual work and group work are typically offered in specialist settings. In London, Ontario, in Canada, groups are available in surrounding towns as well as in the city itself and all relevant agencies are involved in referring to them (Loosley et al., forthcoming 2004).

- Children with more entrenched psychological problems may wait a long time to receive any help, according to feedback from mothers.

- Children of travelling families or refugee or asylumseeking families may be moving around and not able to follow a group programme or series of oneto-one sessions. They may need other ways to access services.

\section{Working with mothers}

As well as undertaking work with children and work with women on their own issues, there is scope - once women are through the worst of the violence - to think about working with them as mothers. This can take various forms. There can be parallel input with mothers whose children are in a group (for example, joint group meetings at the beginning and the end, with separate children's and mothers' groups running side by side in-between). There can also be paired work with mothers and children together to help them rebuild trust and communication, and parenting work with mothers as they move on from their violent partners and take on new responsibilities as the head of the household.

\section{Working in an interdisciplinary context}

Practitioners, who work individually with children living with domestic violence and group workers in this field, can come from a wide range of child care and youthwork backgrounds. It can be particularly practical and fruitful to bring together a team from a range of agencies to resource a rolling group work programme through the year. It is important to remember, however, that agencies with childcare expertise do not automatically know about domestic violence or about group work. Additional training and consultancy can be invaluable (see section on training).

Referrals for direct work can come from any practitioners in touch with women or children, such as women's support workers or children's workers in refuges or other specialist projects, or health and social care, or any other statutory or voluntary sector professionals. They can also come from the mothers themselves. 
A particularly important area for inter-professional cooperation is where there are child protection issues. One specialist domestic violence project found it hard to get social services to accept referrals of children about whom there were wider concerns, and also encountered inappropriate referrals for its own children's services from social workers. Communication was improved by instituting weekly meetings with the relevant duty team in social services. The eventual aim was to align procedures and to have all referrals for intervention with children living with domestic violence, as opposed to child protection, taken by the specialist project in the first instance. An initial assessment sheet for each child identified both the child's and the mother's concerns and what they felt was needed. Experience showed that good assessment was essential since not all referrals were appropriate and not all children were ready for the group. A worst case example was social workers referring to the group, largely to try and extract information about the perpetrator's continuing involvement in the family rather than because they thought the child could benefit from the group. This was part of a wider, somewhat surprising lack of awareness among some social workers in one authority, of the impact of domestic violence on children.

\section{Summing up}

Both individual and group work with children living with domestic violence and its aftermath can help children understand what has happened to them and their mothers, to overcome the negative impact of living with abuse, and to move on in their lives. It can raise awareness, help children learn to keep safe, ensure that they feel less isolated and 'different' and help them feel better about themselves and more confident. It can also be fun.

There was evidence from the evaluations funded under the CRP VAWI that many more children who are living with domestic violence and its aftermath could benefit from these kinds of intervention than are actually being reached. In many parts of England and Wales, there is still no appropriate help available for children. Hence, there is a need for much more of this kind of work. Professionals in other agencies, and sometimes mothers, need help to understand what these positive interventions with children living with domestic violence can offer, within the wider context of children's services. 


\section{References}

Children's Subcommittee of the London Co-ordinating Committee to End Woman Abuse, London, Ontario (1994) 'Make a difference: how to respond to child witnesses of woman abuse', in Mullender, A. and Morley, R. (eds) Children Living with Domestic Violence: Putting Men's Abuse of Women on the Child Care Agenda. London: Whiting and Birch.

Department for Education and Skills (2003) Every Child Matters, DfES publications: Nottingham.

Department of Health, Home Office, Department of Education and Employment (1999) Working Together to Safeguard Children. London: The Stationery Office.

Department of Health, Department of Education and Employment, Home Office (2000) Framework for the Assessment of Children in Need and their families. London: The Stationery Office.

Department of Health (2003) What to do if you are worried about a child being abused. London: Department of Health.

Foote, K. (ed.) (1998) No Violence = Good Health: a group program manual to be used with preschool-aged children who have witnessed family violence, London, Ontario, Canada: Merrymount Children's Centre.

Hester M., Kelly L. and Radford L. (Eds) (1996) Women, Violence and Male Power. Buckingham: Open University Press. HMIC/HMCPSI (2004) Violence at home: a joint thematic inspection of the investigation and prosecution of cases involving domestic violence. London.

Home Office, Department of Health and Crown Prosecution Service (2001) Provision of Therapy for Child Witnesses Prior to a Criminal Trial. Bolton: CPS Communications Branch.

Jaffe I.,Wolfe, D.A., and Wilson, S.K. (1990) Children of battered women. Newbury Park, CA: Sage Publications.

Kitzmann, K.M., Gaylord, N.K., Holt, A.R. and Kenny, E.D. (2003) 'Child witnesses to domestic violence: a meta-analytic review.' Journal of Consultative Clinical Psychology, 71(2): 339-52.

Loosley, S. et al. (forthcoming 2004) Group Work with Children Exposed to Woman Abuse: a manual for practitioners, second edition, London, Ontario, Canada: The Community Group Treatment Program for Child Witnesses of Woman Abuse. (Available from: Susan Loosley, Children's Aid Society of London and Middlesex, P.O. Box 6010, Depot 1, London, Ontario, Canada N5W 5R6.

Loosley, S. and Mullender, A. (2003) 'Gendering work with children and youth', in Cohen, M. B. and Mullender, A., Gender and Group Work. London: Routledge.

Mirrlees-Black C. (1999) Domestic Violence: Findings from a new British Crime Survey self-completion questionnaire. Home Office Research Study No. 191. London: Home Office.

Mullender, A. (2000) Reducing domestic violence... what works? Meeting the needs of children. One of a pack of 12 briefing notes. Crime Reduction Research Series No.4. London: Home Office.

http://www.homeoffice.gov.uk/rds/crimredupubs 1.html

Mullender, A., Hague, G., Imam, U., Kelly, L., Malos, E. and Regan, L. (2002) Children's Perspectives on Domestic Violence, London: Sage.

Mullender, A. and Morley, R. (eds) (1994) Children Living with Domestic Violence: putting men's abuse of women on the child care agenda, London: Whiting and Birch. (Including the chapter by Mullender, A. on 'Groups for child witnesses of woman abuse: learning from North America').

National Children's Home Action for Children (2002) The Hidden Victims: Children and Domestic Abuse. London: NCH Action for Children.

Walby, S. and Myhill, A. (2000) Reducing domestic violence... what works? Assessing and managing the risk of domestic violence. One of a pack of 12 briefing notes, Crime Reduction Research Series No.4. London: Home Office. http://www.homeoffice.gov.uk/rds/crimredupubs 1.html

Walby, S. and Allen, J. (2004) Domestic violence, sexual assault and stalking: Findings from the British Crime Survey. Home Office Research Study No. 276. London: Home Office. 
Wolfe, D. A., Zak., L., Wilson, S. and Jaffe, P. (1986) Child witnesses to violence between parents: critical issues in behavioural and social adjustment. Journal of Abnormal Child Psychology, 14(1): 95-104.

Zink ,T., Elder, N. and Jacobson, J. (2003) Intimate partner violence: How the children affect the mother/victim's process. Arch Paediatric Adolesc Med. June 1, 2003; 157(6): 587-592.

\section{Resources and Materials for Practitioners}

Crime Reduction Programme (CRP) Violence Against Women Initiative (VAWI) resources and materials.

- Camden Safety Net Irene Campbell, Project Director, or Caitriona Scanlon, PO Box 32073, London NW1 9GQ 02079748422

- Cheshire Multiple Interventions

http://www.cheshire.gov.uk/domvio/home.htm

- Sue Bridge, Cheshire Domestic Abuse partnership Chair and project Manager, Social Services Department, County Hall, Chester, $\mathrm{CH} 1$ 1BW.

sue.bridge@cheshire.gov.uk

01244603248

- Lee Rean, Manager Domestic Violence Outreach service, Stonham Housing. 01606351375

- Brendan Murphy \& Judith Gibson, Cheshire Domestic Abuse Partnership Data Monitoring Initiative (based in Cheshire County Council Social Services).

gibson/murphy@cheshire.gov.uk 01244602675

- Police contact: DI Steven Beddows, Constabulary Lead for Domestic Violence and Child Protection, Cheshire Constabulary HQ, Clemonds Hey, Oakemere Road, Winsford, Cheshire CW7 2UA.

steven.beddows@cheshire.pnn.police.uk,

\section{4}

- Education contact: Chris Greenwood, Senior Adviser Child Protection and Domestic Abuse, Education Initiatives in Primary and Secondary Schools. Cheshire County Council Education and Lifelong Learning Department, Woodford Lodge Professional Centre, Woodford lane, Windsford, Cheshire CW7 4EH. chris.greenwood@cheshire.gov.uk

01606814300

- Hastings and Rother Sue Vaughan, Young Person's Manager, 3rd Floor, North West Suite, Tower Point, 44 North Road, Brighton, East Sussex BN1 1YR.

http://www.cri.org

01424716629

- Staying Put Bradford

- Stuart Fogden, Project co-ordinator, PO Box 449, Bradford, B1 2XB.

stuart.fogden@bradford.gov.uk 01274730070

- Alan Caygill, Divisional manager Children and families, City Bradford MBC Social Services, 39 Kirkgate, Shipley, Bradford BD18 3QZ.

alan.caygill@solicana.bradford.gov.uk

- Sunflower Centre Ms Claire Ladlow - Manager, 7-8 Mercers Row, Northampton, NN1 2QL.

01604233684

claire.ladlow@northants.police.pnn.uk 
Background reading and resources for professionals

Children Act 1989 (1989) HMSO, London.

Bridge Project, The (undated) Violence Against Women and Children by Men They Know: a resource pack for group work with children. Leeds: West Leeds Family Service Unit and the NSPCC.

Cleaver, H., Unell, I. and Aldgate, J. (1998) Children's needs- Parenting capacity: the impact of parental mental illness, problem alcohol and drug use, and domestic violence on children's development. London: The Stationery Office.

Department of Health (1991) Children Act 1989 Guidance and Regulations Volumes 1-10. HMSO: London.

Home Office (2003) Safety and Justice: The Government's Proposals on Domestic Violence. London: The Stationery Office.

Humphreys, C., Hester, M., Hague, G., Mullender, A., Abrahams, H. and Lowe, P. (2000) From Good Intentions to Good Practice: working with families where there is domestic violence. Bristol: Policy Press.

Loosley, S. and Mullender, A. (2003) 'Gendering work with children and youth', in Cohen, M. B. and Mullender, A., Gender and Group Work. London: Routledge.

Mooney, J. (1994) The Hidden Figure: domestic violence in North London. London: London Borough of Islington, Police and Crime Prevention Unit (or from Middlesex University, Centre for Criminology).

Mitchell K.J. and Finkelhor, D. (2001) Risk of crime victimisation among youth exposed to domestic violence. Journal of Interpersonal Violence, 16(9) 944-964.

Mullender, A., Hague, G., Imam, U., Kelly, L., Malos, E. and Regan, L. (2002) Children's Perspectives on Domestic Violence. London: Sage.

Mullender, A. and Morley, R. (eds) (1994) Children Living with Domestic Violence: putting men's abuse of women on the child care agenda. London: Whiting and Birch. (Including the chapter by Mullender, A. on 'Groups for child witnesses of woman abuse: learning from North America').

Mullender, A., Burton, S., Hague, G., Imam, U., Kelly, L., Malos, E. and Regan, L. (2003) Stop Hitting Mum!: children talk about domestic violence. East Molesey, Surrey: Young Voice.

Peled, E. and Edleson, J. L. (1995) 'Process and outcome in small groups for children of battered women', in Peled, E., Jaffe, P. G. and Edleson, J. L. (1995) Ending the Cycle of Violence: Community Responses to Children of Battered Women. Thousand Oaks, CA: Sage.

Peled, E. and Davis, D. (1995) Group Work with Children of Battered Women: a practitioner's manual. Thousand Oaks, CA: Sage.

Pickering, F. (2000) Hitting and Hurting: living in a violent family. London: The Children's Society.

Plummer, D. (2001) Helping Children to Build Self-Esteem: a photocopiable activities book. London: Jessica Kingsley Publishers.

Radford L., Sayer S. and AMICA, (1999) Unreasonable Fears: Child Contact in the Context of Domestic Violence - A Survey of Mothers' Perceptions of Harm. Bristol: Women's Aid Federation of England.

Sheffield Domestic Violence Forum (2001) See - Hear - Speak Out: work with children and young people to tackle domestic abuse. Sheffield: Sheffield Domestic Violence Forum, Carver House, 4 Carver Street, Sheffield S1 4FS.

Wilton, T. (undated) My Colouring Book of the Refuge. Bristol: Women's Aid Federation of England.

Wolfe, D. A., Zak., L., Wilson, S. and Jaffe, P. (1986) Child witnesses to violence between parents: critical issues in behavioural and social adjustment. Journal of Abnormal Child Psychology, 14(1): 95-104.

Zink, T., Elder N., and Jacobson. J. (2003) Intimate partner violence: How the children affect the mother/victim's process. Arch Pediatr Adolesc Med. 157: 587-592. 


\section{Sources of advice and guidance for professionals}

Department for Education and Skills (2003). Every Child Matters: Children's Green Paper.

hitp://www.dfes.gov.uk/everychildmatters/

Department for Education and Skills (2004) Every Child Matters: The Next Steps.

hitp://www.dfes.gov.uk/everychildmatters/

Department for Education and Skills. Identification, Referral and Tracking Initiative. Information Sharing to Improve Services for Children Guidance.

hitp://www.cypu.gov.uk/corporate/publications.cfm

Department of Health Guidance (2003) 'What to Do If You Are Worried a Child is Being Abused'.

hitp://www. publications.doh.gov.uk/safeguardingchildren/

Department of Health (2000) Framework for the Assessment of Children in Need and their Families. London: The Stationery Office.

http://www.dh.gov.uk/PublicationsAndStatistics/Publications/PublicationsPolicyAndGuidance/PublicationsPolicyAndG vidanceArticle/fs/en?CONTENT_ID=4003256\&chk=Fss 7 ka

Department of Health, Home Office, Department of Education and Employment (1999) Working Together to Safeguard Children.

http://www.dh.gov.uk/PublicationsAndStatistics/Publications/PublicationsPolicyAndGuidance/PublicationsPolicyAndG vidanceArticle/fs/en?CONTENT_ID=4007781\&chk=BUYMa8

Department of Health (2000) Domestic violence: a resource manual for health care professionals.

hitp://www.doh.gov.uk/pdfs/domestic.pdf.

NHS Confidentiality Code of Practice.

http://www.dh.gov.uk/PublicationsAndStatistics/Publications/PublicationsPolicyAndGuidance/PublicationsPolicyAndG vidanceArticle/fs/en?CONTENT_ID=4069253\&chk=jffKB\%2B

NHS 12 Key Points on Consent.

hitp://www.dh.gov.uk/PublicationsAndStatistics/Publications/PublicationsPolicyAndGuidance/PublicationsPolicyAndG vidanceArticle/fs/en?CONTENT_ID $=4006131$ \&chk=DCfGrJ

General Medical Council Guidance on Patient Confidentiality.

http://www.gmcuk.org/standards/secret.htm

Support and advice for those who have experienced domestic violence

BAWSO (Welsh organisation for Black women who are victims of domestic violence)

02920437390

Broken Rainbow (Pan-London Lesbian, Gay, Bisexual And Transgender Domestic Violence Forum)

07812644914

http://www.lgbt-dv.org/html/rainbow.htm

Careline (Counselling services)

02085141177

Community Legal Service Directory Line

08456081122

http://www.justask.org.uk/index.jsp

Foreign \& Commonwealth Office (Advice on forced marriage)

$02070080135 / 0230$

Home Office Immigration and Nationality Directorate (Advice on immigration and nationality issues)

08706067766

hitp://www.ind.homeoffice.gov.uk. 
Language Line

Translations: 08009176564

Face-to-face interpreting: 08453109900

National Child Protection Helpline (NSPCC)

0800800500

http://www.nspcc.org.uk/nspcc/helpline

National 24-hour Domestic Violence Helpline

08082000247 (minicom available)

Support, help and information, wherever you are in the country. Run jointly by Women's Aid and Refuge, the new Freephone helpline provides access to 24-hour emergency information to thousands of women who suffer at the hands of an abusive partner. It builds on the charities' support services for women and children experiencing domestic violence.

Office of the Deputy Prime Minister (Information and guidance on funding for domestic violence services via the Supporting People programme)

http://www.spkweb.org.uk

http://www.odpm.gov.uk/stellent/groups/odpm_homelessness/documents/page/odpm_home_027994.hcsp

Rape Crisis (For information about rape and sexual abuse, and details about rape crisis support groups)

http://www.rapecrisis.org.uk

Refuge (Refuge operates a network of safe houses and provides outreach services for women)

http://www.refuge.org.uk/

Reunite (UK charity specialising in international parental child abduction)

00162556234

Shelterline - National 24-hour Housing Helpline

08088004444

http://www.shelter.org.uk/housingadvice/shelterline/index.asp

Southall Black Sisters (Advice and support for women from Black and minority ethnic communities)

02085719595

The Samaritans

0345909090

http://www.samaritans.org/

Victim Support

08453030900

http://www.victimsupport.org.uk/

Welsh Women's Aid

02920390874

http://www.welshwomensaid.org/

Women's Aid

01179444411

http://www.womensaid.org.uk

It is a good idea to remind women that they need to be cautious when accessing any of the above websites from a computer that their abuser has access to. The Women's Aid website contains information on action that women can take to minimise the chance of an abuser detecting that they have accessed a site. 


\section{Evidence base for this report}

The Crime Reduction Programme (CRP) Violence Against Women Initiative (VAWI) was an evidence-led programme, which aimed to find out which approaches and practices were effective in supporting victims and tackling domestic violence, rape and sexual assault. In July 2000, 34 multi-agency victim-focused projects were funded, and they developed a range of interventions in various settings and among different population groups. This report is based upon the findings from the independent evaluation of five projects, which were all funded under the CRP VAWI. These projects were selected as one of a number of interventions which they were implementing, related to the provision of direct support to children. The nature and type of support differed depending on the context of the project. However, most provided support to the children of the women they were helping, and these children may have witnessed domestic abuse in the past or were currently living in a household where abuse was occurring.

Although the findings were largely based upon qualitative research and also upon relatively small numbers, they do provide some suggestions for practice, and how best practitioners can intervene to appropriately support children who have or are witnessing domestic violence or abuse.

In addition to the findings from the CRP VAWI, this report draws upon the available published international literature.

\section{Crime Reduction Programme: Violence Against Women Initiative - other reports in the series}

\section{Domestic Violence}

Douglas, N., Lilley, S.J., Kooper, L. and Diamond A. (2004) Safety and justice: sharing personal information in the context of domestic violence - an overview. Home Office Development and Practice Report No. 30. London: Home Office.

Taket, A., Beringer A., Irvine A. and Garfield S. (2004) Tackling domestic violence: exploring the health service contribution. Home Office Online Report No. 52/04, London: Home Office.

Taket, A. (2004) Tackling domestic violence: the role of health professionals. Home Office Development and Practice Report No. 32. London: Home Office.

\section{Rape and sexual assault}

Kelly L., Lovett J., and Regan L. (forthcoming) A Gap or a Chasm? Attrition in Reported Rape cases. Home Office Research Study No. 293. London: Home Office.

Lovett, J., Regan, L. and Kelly, L. (2004) Sexual Assault Referral Centres: developing good practice and maximising potentials, Home Office Research Study No. 285. London: Home Office.

Regan, L., Lovett, J., and Kelly, L. (2004) Forensic nursing: an option for improving responses to reported rape and sexual assault. Home Office Online Research Report 28/04. London: Home Office.

Regan, L., Lovett, J., and Kelly, L. (2004) Forensic nursing: an option for improving responses to reported rape and sexual assault. Home Office Development and Practice Report. No. 31. London: Home Office.

Skinner, T. and Taylor, H. (forthcoming) Providing counselling, support and information to survivors of rape: an evaluation of the Surviving Rape and Trauma After Rape (STAR) young persons' project. Home Office Online Report. London: Home Office.

\section{Acknowledgements}

I would like to express thanks to the many people whose co-operation and assistance was essential to producing this guidance. Firstly, to all of the workers involved with delivering CRP VAWI projects who kindly gave their time, and provided most of the information on which this report is based. I would like to acknowledge the input and cooperation of the other members of the evaluation team, especially to: Ravi Thiara, Gill Hague, Ellen Mallos and Becky Morley. Also thanks to all the people at the Home Office who have supported this project, to Nicola Douglas for managing the evaluation process and to Caitriona O'Kelly and Alana Diamond for editing this report. 
The Research, Development and Statistics Directorate exists to improve policy making, decision taking and practice in support of the Home Office purpose and aims, to provide the public and Parliament with information necessary for informed debate and to publish information for future use.

\section{(C) Crown copyright 2004}

ISSN 14773120

ISBN 1844734935
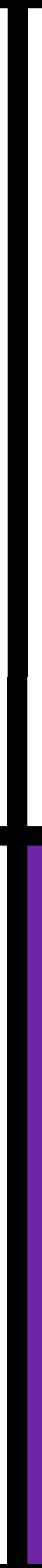

Home Office Development and Practice Reports are produced by the

Research, Development and Statistics Directorate.

Visit our website ot hitp://www.homeoffice.gov.uk/rds 